\title{
ANALISIS PERHITUNGAN HARGA POKOK PRODUKSI DENGAN MENGGUNAKAN METODE FULL COSTING DAN VARIABEL COSTING (STUDY KASUS PADA PERUSAHAAN TENUN GEDOGAN PUTRI RINJANI, KEMBANG KERANG AIKMEL, LOMBOK TIMUR TAHUN 2020
}

\author{
${ }^{1}$ Muhamad Karyadi, ${ }^{2}$ Murah \\ ${ }^{1}$ Prodi Akuntansi, ${ }^{2}$ Prodi Pendidikan Akuntansi \\ ${ }^{12}$ Universitas Gunung Rinjani \\ karyadi@gmail.com \\ yusufmurah@gmail.com
}

\begin{abstract}
Abstrak
Tujuan penelitian ini adalah untuk mengetahui perhitungan harga pokok produksi menurut perusahaan, berdasarkan metode full costing dan variabel costing dan untuk mengetahui perbandingan harga pokok produksi menurut perusahaan dan harga pokok produksi berdasarkan full costing dan variable costing. Jenis penelitian yang dipakai ialah penelitian deskriptif, yaitu penelitian yang berusaha menjabarkan kejadian yang terjadi secara jelas, realistis, aktual, serta saat ini, dikarena peneliti akan melakukan deskripsi, gambaran/lukisan dengan cara sistematis, aktual serta akurat mengenai kenyataan, sifat beserta hubungan antara kejadian yang diteliti. Populasi dari penelitian ini yakni keseluruhan dari jenis barang yang diproduksi oleh perusahaan Tenun Gedogan Putri Rinjani. Sedangkan Sampel yang digunakan didalam penelitian ini ialah jenis barang yang paling diminati yakni tenun ikat dan selendang. Hasil penelitian menunjukan dapat diketahui bahwa Harga Pokok Produksi menurut perusahaan dengan Harga Pokok Produksi menurut metode full costing sama besarnya yaitu 1.007.180.000 sedangkan menurut metode variabel costing sebesar 1.006.180.000, Jadi Harga Pokok Produksi terkecil didapatkan dengan menggunakan metode variabel costing sebesar 1.007.180.000.
\end{abstract}

Kata kunci : Harga Pokok Produksi, Full Costing, Variabel Costing

\begin{abstract}
The purpose of this study was to determine the calculation of the cost of production according to the company, based on the full costing method and variable costing and to compare the cost of goods manufactured by company and the cost of production based on full costing and variable costing. The type of research used is descriptive research, namely research that seeks to describe events that occur in a clear, realistic, actual, and current way, because researchers will carry out descriptions, descriptions/paintings in a systematic, actual and accurate way regarding reality, the nature and the relationship between the event under study. The population of this study is the entire type of goods produced by the Gedogan Putri Rinjani Weaving company. While the sample used in this study is the type of goods that are most in demand, namely ikat and shawl. The results showed that it can be seen that the cost of production according to the company and the cost of production according to the full costing method is the same amount, namely 1.007.180.000 while according to the variable costing method it is 1.006 .180 .000 , so the smallest cost of production is obtained by using the variable costing method of 1.007.180.000.
\end{abstract}

Keywords: Cost of Production, Full Costing, Variable Costing 


\section{PENDAHULUAN}

Berbagai jenis perusahaan yang dikenal dalam dunia bisnis, diantaranya adalah perusahaan manufaktur, ialah perusahaan yang menghasilkan suatu produk melalui proses produksi mengubah bahan mentah menjadi barang jadi, sehingga bisa meningkatkan nilai barang yang dihasilkan.

Dalam ekonomi mikro, produksi ialah mengubah masukan menjadi keluaran atau dapat diartikan seperti proses ekonomi yang memakai sumber daya demi menciptakan sebuah barang yang pas bagi pertukaran. Produksi juga ialah suatu aktivitas yang dilakukan untuk memperbanyak nilai guna suatu barang/menciptakan barang baru hingga makin berguna didalam mencukupi kebutuhan. Ramdhani et al., (2020:14).

$$
\text { Produksi merupakan proses }
$$

menghasilkan sesuatu baik berbentuk barang ataupun jasa didalam suatu periode waktu yang memiliki nilai tambah untuk perusahaan (Fahmi, 2012). Produksi juga merupakan proses penciptaan barang dan jasa (Heizer and Render, 2012). Andi et al., (2020:3).

Produk yang ditawarkan perusahaan dituntut harus berkualitas dan juga memiliki harga yang sesuai dengan kemampuan sehingga bisa menarik minat konsumen untuk membeli. Semua konsumen pasti mengharapkan produk seperti barang dan jasa yang sama seperti kemampuan konsumen untuk membeli produk. Inilah yang menjadi tantangan semua produser untuk membuat produk yang sama dengan minat selera dan kebutuhan pembeli. Dan juga perusahaan juga dapat meningkatkan kualitas produk danjuga dapat meminimalisir biaya produksi.

Bustami dan Nurlela(2013 :7) dalam Iin Sriyani ( 2018).

Sebelum industri membuat harga jual suatu produksi, industri diharuskan menentukan harga pokok nya. Dikarenakan harga penjualan dibuat dengan harga pokok produksi perunit ditambahkan dengan banyaknya keuntungan yang ditentukan industri, karena jika industri tidak menghitung harga pokok produksi perunit maka industri pasti menemukan kesulitan didalam memutuskan harga untuk menjual produk yang dibuat oleh industri.

Menurut Bustomi dan Nurlela (2010:49) dalam Iin Sriyani (2018) harga pokok produksi ialah gabungan suatu biaya didalam awal proses yang dikurangi persediaan produk didalam akhir proses. Adapun menurut T. Horngren (2006:45)"Harga pokok produksi ialah biaya bahan yang dibeli dan diproduksi hingga jadi, baik sebelum ataupun selama periode akuntansi berjalan".

Didalam memutuskan harga pokok produksi ada 2 metode yang dipakai seperti full costing dan variabel costing. Metode full costing ialah cara untuk digunakan didalam memutuskan harga pokok produksi yang seluruh biaya produksi akan dihitung dalam harga pokok produksi. Hingga produksi variabel dan juga biaya produksi tetap tidak berpisah. Karena semua biaya produksi tetap ataupun variabel diposting ke harga pokok produksi, lalu timbul biaya tetap yang sedang ada dalam barang yang belum dijual. Sehingga tidak dibebankannya biaya tetap yang masih ada dalam barang yang belum dijual pada periode yang sebenarnya. Iryanie dan Handayani (2019:11)

Full costing ialah metode untuk membuat kos produk dengan menghitung semua bagian biaya ke kos produksi dan termasuk dalam biaya yang bersifat tetap maupun variabel. Ais Sahla (2020:6).

Menurut Supriyono (2000:15) Full costing menunda adanya pembebanan pada biaya overhead pabrik tetap menjadi biaya waktu barang yang diproduksi terjual. Oleh sebab itu biaya overhead pabrik yang berlangsung masih dianggap sebagai aktiva (dikarenakan berada di akun persediaan) sebelum laku terjual. Tetapi metode variabel costing tidak menunda adanya pembebanan pada biaya overhead pabrik tetap (pada penjelasan lain, tidak setuju dengan pembebanan biaya overhead pabrik tetap ke produk tersebut yang belum terjual, maka pembebanan BOP bertambah atau berkurang).

Sedangkan metode variabel costing yaitu cara untuk membuat harga pokok produk dan hanya membebankan biaya produk variabel saja. Mulyadi (2015:122). Variabel Costing ialah cara menentukan harga pokok produksi dan hanya menghitung biaya produk berperilaku variabel yang ada didalam biaya bahan baku, tenaga kerja langsung, serta overhead pabrik. Ais Sahla (2020:7)

Didalam metode biaya variabel, BOP tetap dianggap sebagai biaya periode (Seluruh biaya selain harga pokok produk) dan tidak sebagai bagian harga pokok produk, jadi biaya 
pada saat periode berjalan overhead pabrik tetap dibebankan. Oleh karena itu, BOP tetap didalam metode variabel costing tidak terdapat di persediaan harga pokok yang belum terjual, tapi diakui sebagai biaya produksi pada periode berjalan. Mulyadi (2005:124)

Seperti yang dijelaskan oleh Herman Wibowo dan Alfonsus Sirait didalam buku Akuntansi Biaya Perencanaan dan Pengendalian (1994:202) menjelaskan bahwa: Kelemahan konsep full costing ialah biasanya tidak berkaitan dengan pengendalian manajemen jangka pendek. Seperti untuk menganalisa berubahnya biaya, volume, laba jangka pendek, pada batas kinerja produksi normal yang perusahaan miliki dibutuhkan ancangan yang menarik minat dibagian biaya variabel, seperti biaya relevan yang berganti disesuaikan dengan tingkat volume aktivitas pada jangka pendek. Selain mempunyai kelemahan, konsep full costing method juga memiliki kelebihan yaitu konsep full costing method yaitu rencana tetap yang sudah diterima umum, adapun pihak extern perusahaan lebih mudah mengerti. Konsep full costing method digunakan Pihak fiskus untuk memutuskan besarnya pajak penghasilan suatu perusahaan.

Dalam metode variabel costing, Menurut Dr. R.A Supriyono, S.U., Akuntan (2014:308) terdapat kelebihan diantaranya:Memudahkan dalam merencanakan laba jangka pendek, memudahkan dalam menentukan harga jual suatu produk, memudahkan dalam mengambil keputusan, memudahkan dalam mengendalikan biaya. Sedangkan kelemahan Metode variable costing yaitu naik turunnya keuntungan dikaitkan dengan perubahan didalam pemasarannya. Bagi perusahaan yang memiliki usaha tidak tetap, pada periode tertentu penggunaan variable costing akan mendapatkan kerugian yang besar, tetapi didalam periode lainnya bisa mendapatkan keuntungan yang tidak stabil. Penyusunan laporan laba rugi dengan metode full costing lebih bermanfaat dari laporan yang dibuat berdasarkan variabel costing, karena tidak memperhitungkan BOP tetap didalam harga pokok persediaan dan persediaan akan membuat nilai persediaan semakin menurun, hingga bisa menurunkan modal kerja yang kita laporkan pada tujuan analisis keuangan. Uzry (2009:80) dalam Vorarouw (2013).

Terdapat beberapa hasil penelitian terdahulu yang sudah dilakukan terkait pada variabel costing dan full costing diantarnya Djumali (2014) Hasil penelitian menerangkan jika menghitung harga pokok produksi perusahaan memakai variabel costing terdapat perbedaan harga jual yaitu bagi perusahaan lebih tinggi harganya dari pada menggunakan metode variabel costing. Cahyani (2015) Hasil penelitian menerangkan jika perhitungan harga pokok produksi yang memakai metode full costing lebih besar dibandingkan perhitungan metode perusahaan.

Hadi (2015) Hasil penelitian menunjukkan bahwa penggunaan metode variabel costing ini sangat relevan dipakai dalam mengambil keputusan. Rohmiatun (2016) Hasil penelitian menunjukkan bahwa biaya yang dikeluarkan didalam metode full costing lebih besar dibandingkan menggunakan variabel costing. Sriyani (2018) Hasil penelitian menerangkan jika menghitung HPP pada metode full costing lebih tinggi daripada menggunakan variabel costing.

Tenun Gedogan Putri Rinjani adalah salah satu industri yang bergerak dalam bidang produksi berbagai kain tenun tradisional, yang berlokasi di Desa Kembang Kerang, Kecamatan Aikmel, Kabupaten Lombok Timur. Kain Tenun Gedogan Putri Rinjani pertama kali didirikan oleh ibu Nur'aini S.Pdi pada tahun 2003.

Kegiatan produksi sangat berpengaruh terhadap laba yang diperoleh.Untuk itu, dalam proses pembuatannya harus dilakukan dengan baik supaya usahanya dapat berjalan dengan lancar. Untuk memperoleh laba dari penjualan produknya. Pemilik usaha kain tenun gedogan putri rinjani harus menentukan biaya produksi yang dikeluarkan. Biaya yang timbul dari proses produksi ini harus dikontrol dengan baik agar tidak terlalu rendah atau tidak terlalu tinggi. Dengan demikian penulis menyarankan agar pemilik usaha harus memahami betul metode yang digunakan untuk menentukan harga pokok produksi dapat memperoleh laba yang diinginkan. Adapun jenis yang diproduksi oleh usaha kain tenun gedogan putri rinjani antara lain : 
Daftar tabel 1.1

Jenis barang yang diproduksi oleh perusahaan Tenun Gedogan Putri Rinjani.

\begin{tabular}{|c|l|l|}
\hline No & PRODUK & PRODUK TURUNAN \\
\hline 1 & Motif & Sepatu \\
2 & Tenun Ikat & Tas \\
3 & Tenun Seri Menanti & Baju \\
4 & Selendang & \\
5 & Songket & \\
\hline
\end{tabular}

Sumber : Daftar Produk Kain Tenun Gedogan Putri Rinjani

Produksi usaha ini menggunakan berbagai macam bahan dan alat yang digunakan sehingga menyerap biaya yang tinggi. Oleh karena itu diperlukan kecermatan dalam menghitung biaya yang dikeluarkan. Perhitungan biaya produksi sangat berpengaruh terhadap penentuan harga pokok produksi dan penentuan harga jual produk tsb.

Berdasarkan uraian diatas, maka penulis memilih perusahaan Tenun Gedogan Putri Rinjani sebagai objek penelitian karena didalam perhitungan Harga Pokok Produksi yang digunakan Industri Tenun tidak sama perhitungannya dengan metode variabel costing serta full costing. Sehingga peneliti tertarik ingin membuat penelitian yang berjudul : Analisis Perhitungan Harga Pokok Produksi Dengan Menggunakan Metode Full Costing Dan Variabel Costing (Study Kasus Pada Perusahaan Tenun Gedogan Putri Rinjani,Kembang Kerang Aikmel,Lombok Timur Tahun 2020).

\section{RumusanMasalah}

Dari latar belakang tersebut, terdapat beberapa rumusan masalah diantaranya sbb:

1 Bagaimana perhitungan harga pokok produksi menurut perusahaan?

2 Bagaimana perhitungan harga pokok produksi berdasarkan metode full costing dan variabel costing?

3 Bagaimana perbandingan harga pokok produksi menurut perusahaan dan harga pokok produksi berdasarkan full costing dan variable costing?

\section{TINJAUAN PUSTAKA}

Indro Djumali (2014) judul penelitian "Perhitungan Harga Pokok Produksi Dengan Memakai Metode Variabel Costing Didalam Penetapan Harga Jual Di PT. Sari Malalugis Bitung. Metode analisa yang dipakai ialah analisa deskriptif. Hasil penelitian menyimpulkan jika didalam menghitung HPP menurut perusahaan lebih tinggi dibandingkan metode variabel costing.

Cahyani (2015) Judul penelitian “ Analisis Perhitungan Harga Pokok Produksi Menggunakan Metode Full Costing Pada Pabrik Tahu Sari Langgeng Kutoarjo. Tujuan dari penelitian ini yaitu untuk menganalisa perbandingan perhitungan kos produk menurut metode full costing dengan perhitungan menurut perusahaan. Hasil penelitian meyimpulkan jika perhitungan harga pokok produksi berdasarkan full costing lebih tinggi dari pada menurut perusahaan .

Hadi (2015) Judul penelitain "Analisis Penentuan Harga Pokok Produksi Dengan Menggunakan Metode Variabel Costing Dan Full Costing, tempat penelitian pada UD. Cahaya Rembulan Kecamatan Pringgabaya Kabupaten Lombok Timur. Penelitian ini bertujuan untuk menentukan perhitungan harga pokok produksi serta perbedaan perhitungan harga jual produksi es balok dengan memakai variabel costing dan full costing. Data diperoleh melalui observasi, wawancara, serta dokumentasi. Hasil penelitian menerangkan bahwa didalam mengambil keputusan penggunaan metode variabel costing ini lebih relevan digunakan.

Rohmiatun (2016) judul penelitian "Analisis Perhitungan Harga Pokok Produksi Dengan Menggunakan Metode Full Costing Dan Variabel Costing Study Kasus Di Industri Rumah Tanggan UD.Nandita Pancor Lombok Timur. Tujuan dari penelitian ini ialah untuk memahami bagaimana perhitungan biaya produksi berdasarkan full costing dan variabel costing. Data didapatkan melalui observasi, wawancara, serta dokumentasi. Hasil penelitian menerangkan jika biaya yang dikeluarkan dalam pemakaian metode variabel costing lebih kecil dibandingkan dengan full costing.

Sriyani (2018) judul penelitian“ Analisis Perhitungan Harga Pokok Produksi 
Dengan Metode Full Costing Dan Variabel Costing (Studi Kasus Pt. Bima Desa Sawita Medan) “. Tujuan dari penelitian ini yaitu menganalisa perbandingan perhitungan harga pokok produksi dengan menggunakan metode full costing dan metode Variabel Costing. Didalam penelitian ini data yang dipakai adalah data kualitatif dan kuantitatif. Hasil penelitian menyimpulkan jika perhitungan harga pokok produksi berdasarkan metode variabel costing lebih sedikit dari pada memakai metode full costing.

Oktaviani (2019) judul penelitian “Analisis Perhitungan Harga Pokok Produksi Dengan Metode Full Costing Studi Kasus Pada Cv. Lestari Albasia Mandiri". Tujuan dari penelitian ini yaitu untuk menganalisa tentang keakuratan didalam menghitung harga pokok produksi didalam perusahaan. Sumber data yaitu observasai, wawancara dan dokumentasi. Penelitian ini menjelaskan jika perhitungan harga pokok produksi yang ada didalam teori tidak sama dengan perhitungan dari perusahaan. Teori yang dipakai yaitu teori dengan perhitungan memakai metode full costing, dimana semua biaya produksi akan dihitung. Perhitungan Harga pokok produksi menurut metode full costing lebih besar dibandingkan menurut perusahaan.

Sunanda (2019) judul penelitian "Analisis Harga Pokok Produksi Dengan Memakai Metode Full Costing, Variable Costing Dan Activity Based Costing Dalam Menentukan Harga Jual Produk Pada Rolasz Group (Studi Kasus Pada Usaha Konfeksi Rolasz Group). Penelitianan ini memiliki tujuan untuk menganalisis bagaimana perhitungan HPP yang dipakai oleh Rolasz Group. Jenis metode yang akan dipakai didalam penelitian ini yaitu metode kualitatif dan kuantitatif. Kesimpulkan pada hasil penelitian ini yaitu bahwa metode perhitungan biaya produksi serta harga jual yang dipakai oleh Rolasz Group memiliki hasil yang sama seprti perhitungan biaya produksi dan harga jual dengan memakai metode full costing. Perhitungan dengan memakai metode variable costing hasilnya lebih sedikit dari pada perhitungan metode full costing, sementara itu hasil perhitungan dengan metode activity based costing hasilnya lebih rendah dari perhitungan dengan metode variable costing .

Sulastri (2019) judul penelitian

"Analisis Perhitungan Harga Pokok Produksi Dengan Menggunakan Metode Full Costing
Dan Metode Variabel Costing di Warung Pempek Nony 168 Palembang Cabang Radial". Tujuan dari penelitian ini yaitu menghitung, menganalisa dan juga membandingkan HPP menurut metode full costing, metode variabel costing dan metode konvensional. Hasil penelitian menyimpulkan jika perhitungan harga pokok produksi dengan menggunakan metode konvensional lebih kecil HPP nya dari pada menggunakan metode variabel costing dan full costing.

Febrianty (2020) judul penelitian "Analisis Perhitungan Harga Pokok Produksi Dengan Metode Full Costing Dan Variabel Costing. (Studi Kasus Di Perusahaan Daerah Air Minum Tirta Je'neberang Kabupaten Gowa). Penelitian ini memiliki tujuan untuk melihat bagaimana perhitungan HPP yang memakai variabel costing dan full costing. Bentuk penelitian yang dipakai yaitu bentuk kuantitatif. Dengan menggunakan pendekatan deskriptif. Data yang dipakai adalah data sekunder seperti laporan keuangan yang didapatkan langsung dari perusahaan. Sementara data lainnya didapatkan dari jurnal, buku, dan internet. Hasil penelitian menerangkan jika harga pokok produksi berdasarkan full costing lebih tinggi dibandingkan perhitungan harga pokok produksi yang memakai variable costing .

\section{Landasan Teori}

\section{Pengertian Akuntansi}

Akuntansi diartikan sebagai sebuah metode mencatat, menggolongkan, pengikhtisaran, terhadap transaksi keuangan yang dilakukan secara sistematis dan kronologis disajikan didalam laporan keuangan yang berguna bagi pihak yang membutuhkan laporan keuangan tersebut untuk langkah pengambilan keputusan. SastroAdmodjo (2021:1). "Akuntansi ialah sebuah sistem informasi keuangan, yang bertujuan membuat dan juga melaporkan informasi yang benar bagi lembaga yang memiliki kepentingan". Hans Kartikahadi, dkk. (2016:3).

Menurut Wahyuni Nur (2020:10). Menyajikan informasi ekonomi dari satu kesatuan ekonomi kepada pihak yang memiliki kepentingan merupakan tujuan utama akuntansi. Adapun tujuan informasi akuntansi sbb:

1 Menyimpan serta mengumpulkan data mengenai kegiatan transaksi.

2 Memproses data jadi informasi yang bisa dipakai didalam proses mengambil 
keputusan mengenai perencanaan serta pengendalian bisnis.

3 Melakukan kontrol dengan benar tentang aktiva perusahaan.

4 Efisiensi waktu dan biaya tentang kinerja keuangan.

5 Menyajikan data keuangan yang akurat dan sistematis didalam periode akuntansi yang tepat.

Kesimpulan dari tujuan informasi akuntansi diatas yaitu didalam mengelola keuangan secara baik dan benar baka diperlukan sistem informasi akuntansi sangat membantu perusahaan. Selain menekan biaya serta waktu, informasi akuntansi juga memudahkan perusahaan dalam pengambilan keputusan yang akurat untuk kinerja bisnis selanjutnya.

\section{Akuntansi Biaya}

Yaitu proses mencatat, menggolongkan, meringkasa serta menyajikan biaya, membuat produk maupun jasa, dengan cara tertentu, juga penjelasannya. Dan biaya yaitu objek kegiatan dari akuntansi biaya. Proses akuntansi biaya dilakukan untuk memenuhi kepentingan pengguna informasi biaya didalam perusahaan. Oleh sebab itu akuntansi biaya harus mengamati ciri-ciri manajemen akuntansi. "Yakni akuntansi biaya adalah bagian dari akuntansi manajemen" (Mulyadi,2016:7).

Tujuan akuntansi biaya menurut Iryanie dan Handayani (2019:1)

1 Mencatat, menggolongkan, dan juga meringkas biaya pembuatan produksi merupakan cara penentuan harga pokok produksi.

2 Memberikan informasi biaya bagi kepentingan manajemen: karena biaya merupakan bentuk dari suatu efisien.

3 Sebagai alat perencanaan: merencanakan bisnis sangat berhubungan oleh pendapatan danbiaya, karena perencanaan biaya bisa mempermudah manajemen didalam mengendalikan biaya.

4 Pengendalian biaya:Mengendalikan biaya yang sebenarnya digunakan untuk membuat produk memakai biaya yang ada.

5 Memperkenalkan metode: beragam jenis metode didalam akuntansi biaya bisa dipakai sesuai pada kepentingan yang akan dibutuhkan.

6 Perhitungan laba perusahaan : untuk melihat keuntungan perusahaan bahwa dibutuhkan biaya yang sebenarnya digunakan, karena biaya bagian dari laba.

7 Mengambil keputusan khusus: untuk bahan manajemen dalam melihat serta mengawasi transaksi biaya dengan teratur dan penyajian informasi biaya didalam karakter laporan biaya.

8 Menganalisa dan menghitung ketidak efektifan serta ketidak efisienan: menyebutkan batas maksimum yang diikuti didalam penetapan biaya produk, menganalisa serta menetapkan pilihan terbaik bila terjadi perbedaan batas maksimal dengan yang sebenarnya terjadi.

Fungsi akuntansi biaya menurut Iryanie dan Handayani (2019:4)

1 Membuat perhitungan serta melaporkan biaya atau harga pokok dalam produksi.

2 Menghitung biaya atau harga pokok produk ke semua unsur biaya.

3 Membagikan informasi mendasar dalam melakukan suatu perencanaan biaya.

4 Membagikan data karena data merupakan suatu proses dari pembuatan anggaran.

5 Membagikan informasi biaya untuk dipakai didalam pengendalian manajemen.

\section{Pengertian Biaya}

"Biaya yaitu mengorbankan ekonomi yang dapat diukur didalam satuan uang, yangakan terjadi/yang sudah terjadi untuk tujuan tertentu. Mulyadi (2014:8) Terdapat 4 bagian didalam pengertian biaya adalah:

1 Pengorbanan ekonomi

2 Diakui sebagai uang

3 Untuk tujuan tertentu.

4 Yang akan terjadi atau terjadi

"Menurut Amin Widjaja Tunggal (2014:8) didalam Astuti (2018) "Biaya yaitu nilai keuangan saat ini serta pengorbanan sumber ekonomi untuk mendapatkan barang serta jasa".

Sedangkan menurut Purwanti dan Prawironegoro (2014:19) didalam Astuti (2018) "Biaya merupakan pengorbanan kas atau setara kas untuk membuat barang dan jasa sehingga mendapatkan keuntungan atau manfaat dimasa yang akan datang".

Kriteria biaya menurut Prawirosentono (2009:121) adalah:

1 Dapat diperkirakan sebelumnya, karena berhubungan dengan kegiatan usaha.

2 Tidak bisa dihindarkan, karena tanpa pengorbanan tidak bisa menjalankan usaha.

3 Dapat diukur dengan nilai uang. 


\section{Penggolongan Biaya}

Mulyadi (2016:13) Akuntansi biaya tergolong dalam beragam penggolongan, yaitu penggolongan biaya harus ditetapkan dengan berbagai tujuan yang akan diambil. karena akuntansi biaya dikenal dengan konsep: "biaya yang berbeda untuk tujuan yang berbeda".

Mulyadi mengemukakan jika biaya bisa digolongkan berdasarkan sifatnya :

1 Penggolongan biaya berdasarkan objek yang dikeluarkan.

Nama akun pengeluaran adalah dasar atas penggolongan biaya. Seperti akun pengeluaran yaitu air dan listrik jadi seluruh pengeluaran yang berkaitan dengan air dan listrik ditulis dengan akun biaya air dan listrik. (Mulyadi,2016:13).

2 Penggolongan biaya berdasarkan fungsi pokok.

Didalam organisasi industri, fungsi pokok terbagi atas 3 bagian, ialah fungsi pemasaran, produk, serta administrasi dan umum. Dengan begitu didalam industri, biaya bisater bagi dalam 3 kelompok:

(a) Biaya produksi

Yaitu biaya yang ada pada saat memproduksi bahan mentah menjadi produk jadi yang sedia untuk dipasarkan. Secara garis besar, menurut objek pengeluarannya biaya produksi terbagi dalam 3 faktor yaitu : biaya bahan baku, tenaga kerja langsung, serta overhead pabrik (factory overhead cost). Contohnya seperti Penyusutan langsung atau tidak langsung mesin dan peralatan selama proses produksi, biaya bahan baku, biaya bahan penolong, dan upah pegawai di bagian produksi.

(b) Biaya pemasaran

Yaitu berlaku untuk biaya pelaksanaan tindakan pemasaran produk. Misalnya yaitu biaya promosi, biaya iklan, biaya transportasi dari tempat produksi kegudang konsumen.

(c) Biaya administrasi dan umum

"Yaitu biaya koordinasi aktivitas pemasaran dan juga produksi. Contohnya yaitu gaji karyawan dari bagian keuangan, akuntansi, personalia serta elemen dari ikatan kemasyarakatan, biaya audit, dan juga biaya photocopy" (Mulyadi,2016:14) dalam Ais Sahla (2020:3)

\section{Harga Pokok Produksi}

Yaitu seluruh elemen biaya yang dipakai didalam pembuatan produk jadi seperti biaya bahan mentah, biaya kerja langsung, dan biaya overhead pabrik" (Hanggana,2008:19) dalam (Rohmiatun:2016). Mulyadi (2015:14) "Harga pokok produksi yaitu semua biaya yang dipakai didalam pembuatan barang dan jasa pada waktu tertentu. Penjelasan lainnya, harga pokok produksi ialah biaya yang dipakai untuk memperoleh produk jadi yang sediauntuk dijual."

Sedangkan seperti yang ditunjukkan oleh Bustami dan Nurlela (2010:49): "Komponen biaya produksi terdiri dari bahan baku, tenaga kerja langsung, dan biaya overhead pabrik dan juga persediaan produk proses awal dan dikurangi produk didalam proses akhir."

\section{Manfaat Harga Pokok Produksi}

Mulyadi (2015:65) manfaat harga pokok produksi yaitu:

1 Membuat harga jual produksi.

Didalam membuat harga jual produk, data yang dihitung adalah biaya produksi satu unit, selain data produksi juga data non biaya.

2 Alat pantau proses biaya produksi.

Akuntansi biaya dipakai dalam menampung informasi biaya yang dipakai didalam proses produksi dalam periode tertentu untuk melihat apakah suatu produksi memakan seluruh biaya yang sama seperti yang dianggarkan.

3 Menghitung laba rugi periode tertentu.

Informasi laba digunakan untuk memahami pemberian produk didalam memperoleh laba/rugi dan memenuhi biaya non produksi. Oleh sebab itu,informasi biaya produksi yang sudah dipakai dibutuhkan manajemen untuk membuat produk didalam waktu tertentu.

4 Menetukan harga pokok produk didalam proses dan produk jadi yang dibuat didalam neraca.

Saat manajer merancang keputusan keuangan periodik, manajer membuat laporan keuangan seperti neraca dan laba rugi. Didalam neraca, manajer diwajibkan membuat HPP masih berproduksi dan HPP produk jadi. Untuk mencapai tujuan manajemen , maka manajemen harus membuat catatan tiap periode.

\section{Metode Perhitungan Harga Pokok Produksi 1 MetodeFull Costing}

"Yaitu carauntuk penentuan harga pokok produksi yang mana seluruh biaya produksi diperhitungkan didalam harga pokok 
produksi" (Iryanie dan handayani, 2019:11). "Full costing ialah proses menentukan HPP yang menghitung seluruh elemen biaya kedalam harga pokok yang mencakup biaya bahan baku, tenaga kerja langsung, serta overhead pabrik, baik yang bersifat tetap ataupun variabel."'(Ais Sahla ,2020:6).

Menurut Mulyadi (2014:17) : Definisi full costing yaitu metode untuk menentukan harga pokok produksi, yang mencakup biaya bahan baku, tenaga kerja langsung, dan overhead pabrik, baik yang berperilaku tetap ataupun variabel, jadi berdasarkan full costing harga pokok produksi termasuk dalam elemen biaya produksi.

Biaya bahan baku Rp. xxx

Biaya Tenaga kerja langsung Rp. $x x x$

Biaya overhead pabrik tetap Rp. $x x x$

Biaya overhead pabrik variabel Rp. xxx

Harga Pokok Produksi Rp. xxx

Biaya bahan baku ialah semua biaya penerimaan barang dan akan dijadikan komponen dari objek biaya (barang yang diproses kemudian menjadi barang yang

siap untuk dijual) dan bisa dimasukkan kebagian biaya dengan sistem yang ekonomis.

1 Biaya tenaga kerja langsung/upah langsung yaitu biaya yang dikeluarkan untuk tenaga kerja langsung yang bekerja dengan langsung didalam proses produksi.

2 Biaya Overhead pabrik merupakan semua biaya produksi yang berhubungan dengan biaya tapi tidak bisa ditemukan dibagian biaya (barang didalam pembuatan dan menjadi bahan siap untuk dijual) dengan sistem ekonomi. Contohnya seperti: Biaya bahan pembantu, tenaga kerjanonproduksi, perbaikan, depresiasi peralatan pabrik, Perbaikan mesin pabrik, dan perbaikan gedung pabrik (Sofia Prima Dewi, 2014:21).

3 Biaya Overhead pabrik terbagi dalam 3 bagian:

(a) Biaya Overhead pabrik tetap yaitu Biaya yang tidak dapat beralih pada putaran peralihan proses pekerjaan yang khusus.

(b) Biaya Overhead pabrik variabel ialah Biaya yang beralih pada saat peralihan proses pekerjaan.

(c) Biaya Overhead pabrik semivariabel yaitu Biaya yang tidak beralih pada saat peralihan proses pekerjaan (Mulyadi,2016: 195) dalam Ais Sahla (2020:6).
Menurut Sriyani (2018) Pendektan tradisional yang biasa disebut dengan pendekatan full costing membuat laporan laba rugi yang dimana biaya diatur dan dibuat menurut, fungsi administrasi, produksi, dan penjualan. Dari pendekatan full costing ini, laporan laba rugi yang diwujudkan banyak dipakai untuk memberikan pihak eksternal perusahaan, oleh sebab itu prosedurnya diharuskan sesuai sama prinsip akuntansi yang berlaku untuk membuktikan informasi yang tersedia didalam laporan.

\section{Kelemahan dan Kelebihan Metode Full Costing}

Menurut Supriyono (2000:15) terdapat kelemahan serta kelebihan yang kita dapatkan apabila memakai metode full costing. Adapun kelebihannya yaitu :

1 Memperlihatkan biaya overhead sesungguhnya karena memuat 2 jenis biaya overhead yaitu tetap dan variable.

2 Full Costing bisa menunda pembebanan biaya overhead waktu produk belum laku dijual.

3 Pembebanan biaya overhead pada barang yang belum laku bisa dipindahkan untuk mengurangi/menambah harga pokok didalam persediaan kita.

Selain kelebihan diatas metode full costing juga memiliki kelemahan yaitu, membuat harga penjualan semakin tinggi dari pada memakai variable costing. dikarenakan metode full costing beranggapan bahwa konsumen berani membeli berapapun harga barang. Metode ini bagus bagi perusahaan yang sudah memiliki bahan pokok masyarakat.

\section{Metode Variabel Costing}

Ialah proses menentukan harga pokok produksi yang menghitung biaya produksi berperilaku variabel yang terdapat dalam biaya bahan baku, tenaga kerja langsung, serta overhead pabrik. Ais Sahla (2020:7).
Menurut
Mulyadi
(2014:18)

Pengertian metode variable costing ialah cara perhitungan biaya produksi yang berperilaku variabel kedalam harga pokok produksi didalam menentukan harga pokok produksi, yang terdapat dalam biaya bahan baku, tenaga kerja langsung serta biaya overhead pabrik variabel.

Didalam metode variabel costing, biaya overhead pabrik tetap dibutuhkan sebagai biaya periode serta tidak sebagai elemen HPP, sehingga BOP tetap diakui 
menjadi biaya didalam periode berjalan. Dengan begitu BOP tetap didalam metode variabel costing tidak berada di persediaan pokok yang belum terjual, tapi langsung diakui sebagai biaya pada periode terjadinya. Mulyadi,(2005:18)

Harga pokok produksi terdiri dari bagian-bagian biaya produksi berdasarkan metode variable costing sbb:

$\begin{array}{lc}\text { Biaya bahan baku } & \text { Rp. Xxx } \\ \text { Biaya tenaga kerja langsung } & \text { Rp. xxx } \\ \text { Biaya overhead pabrik variabel } & \text { Rp. xxx } \\ \text { Harga Pokok Produksi } & \text { Rp. xxx }\end{array}$

Harga Pokok Produksi Rp. xxx

Tujuan dari variabel costing yaitu untuk mencukupi manajer didalam mendapatkan informasi yang mempunyai orientasi didalam mengambil keputusan jangka pendek, yaitu:

1 Pihak manajemen bisa tahu batas wewenang yang bermanfaat untuk membuat rencana besarnya laba dari analisa hubungan biaya-volume-laba serta untuk keputusan bagi pihak manajemen didalam pengambilan kebijaksanaan jangka pendek.

2 Pihak manajemen lebih mudah didalam mengontrol situasi aktivitas yang berlangsung, menentukan penilaian dan melakukan pertanggungjawaban kepada bagian lainnya didalam suatu perusahaan. (Supriyono)

Manfaat Metode Penentuan Harga Pokok Variabel Costing

1 Perencanaan Laba

Proses menentukan harga pokok variabel bagi manajemen bisa bermanfaat dalam merencanakan laba jangka pendek. Dengan terpisahnya seluruh biaya produk kedalam biaya tetap dan variabel juga perhitungan batas kewenangan, melalui persamaan hubungan biaya-volume-laba.

2 Penentuan Harga Jual Produk

Proses menentukan harga pokok variabel berguna bagi manajemen didalam penentuan harga penjualan didalam jangka pendek, dengan memakai hubungan (cost-volume-profit analysis). Dalam penentuan harga pokok variabel, manajemen juga dapat menggunakannya didalam menentukan harga jual terendah atas special orders (pesanan khusus) didalam jangka pendek yang mungkin diterima perusahaan, supaya perusahaan tidak mendapatkan kerugian akibat pesanan khusus tersebut. Supriyono (2014:308)

Dengan penentuan harga pokok variabel persyaratan pesanan khusus yang bisa diambil adalah:

(a) Volume penjualan juga produksi perusahaan belum penuh (masih ada yang tersisa), dikarenakan jika melewati volume penuh akan mengakibatkan berubahnya jumlah biaya tetap.

(b) Dalam penjualan pesanan khusus dengan penjualan biasa dilakukan pembagian pasar, supaya tidak terpengaruh harga jual yang biasa lebih tinggi ikut turun. Misalnya produk akan digunakan sendiri oleh pembeli. Supriyono(2014:308)

\section{Kelemahan Metode Variabel Costing}

1 Memisahkan semua biaya sepertibiaya variabel dan biaya tetap tidak mudah dilakukan, dikarenakantidak banyak suatu biaya betul-betul variabel atau betul-betul tetap. Suatu biaya dapat dikatakan variabel jika:

(a) Nilai barang dan jasa tetap.

(b) Proses produksi yang digunakan tetap.

(c) Kemampuan tetap.

Sedangkan biaya tetap terbagi dalam 2 yaitu :

(a) Berubahnya biaya tetap didalam jangka pendek, contohnya biaya pemasaran dan produksi, gaji manajer akuntansi, keuangan, dll.

(b) Tidak berubahnya biaya tetap didalam jangka panjang, contohnya biaya sewa kantor yang disewakan untuk jangka panjang yang bersifat variabel.

2 Tidak digunakannya prinsip akuntansi yang berlaku. Dikarenakan variable costing hanya digunakan untuk mencukupi kebutuhan didalam perusahaan saja.

3 Didalam metode variable costing turun naiknya keuntungan dikaitkan dengan berubahnya didalam proses pemasaran.

4 Didalam harga pokok persediaan dan persediaan biaya overhead pabrik tetap tidak dihitung sehingga membuat nilai persediaan akan ternilai lebih kecil, jadi akan mengurangi modal kerja yang dilaporkan untuk kepentingan analisis keuangan. Mulyadi

(2015:150) 
Gambar 2.1 Kerangka Konseptual

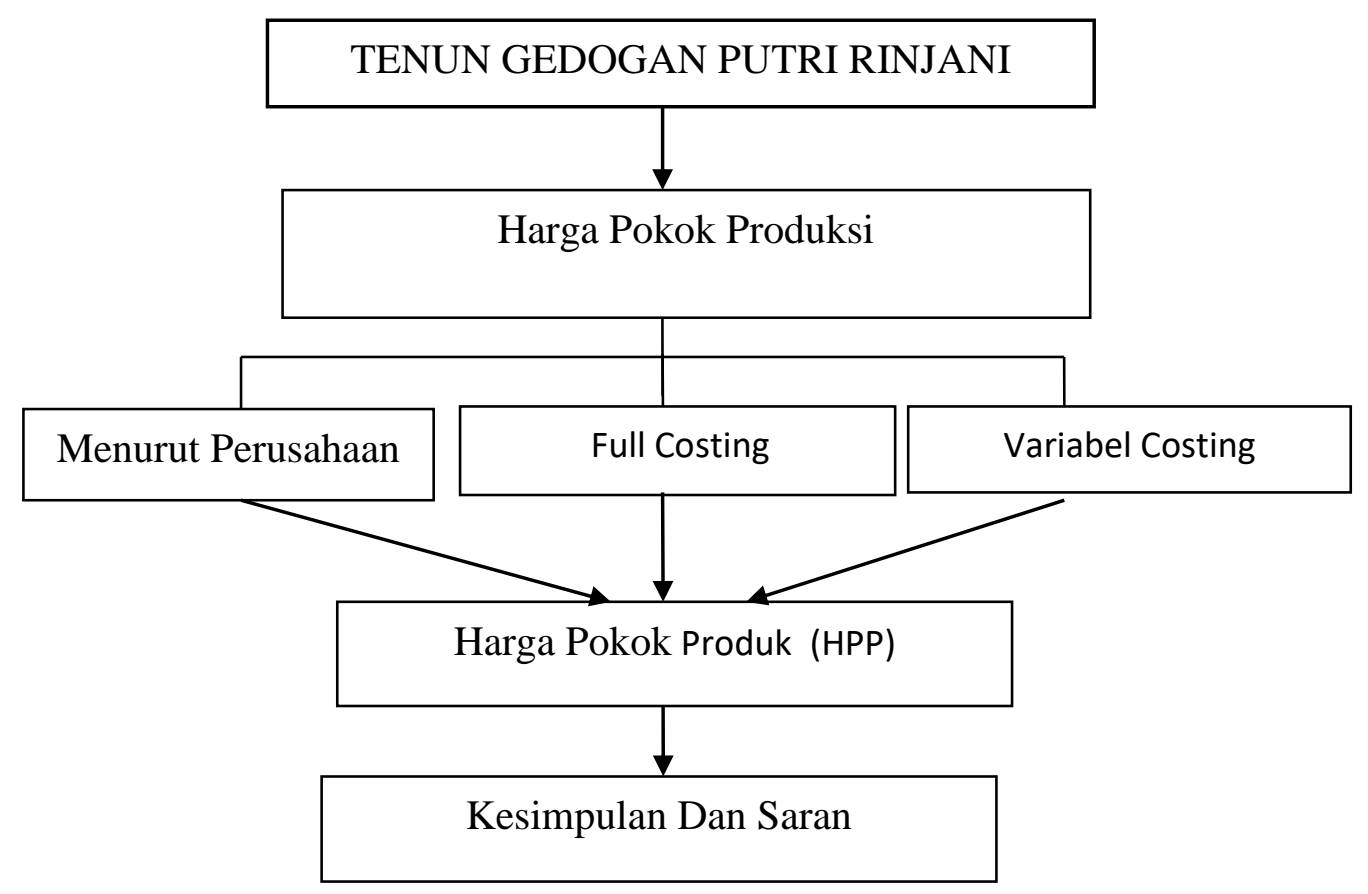

\section{METODE PENELITIAN}

Jenis penelitian yang dipakai ialah penelitian deskriptif, yang bergerak untuk menyatakan penyelesaikan masalah yang timbul sekarang bersumber dari data, maka dari itu juga ia melakukan penyajian data, penganalisisan data, serta penginterpretasian data. (Narkubo dan Ahmadi,2005:44).

Menurut Rukajat (2018:1) Penelitian deskriptif ialah penelitian yang berusaha menjabarkan kejadian yang terjadi secara jelas, realistis, aktual, serta saat ini, dikarena peneliti akan melakukan deskripsi, gambaran/lukisan dengan cara sistematis, aktual serta akurat mengenai kenyataan, sifat beserta hubungan antara kejadian yang diteliti.

Populasi dari penelitian ini yakni keseluruhan dari jenis barang yang diproduksi oleh perusahaan Tenun Gedogan Putri Rinjani. Adapun Jenis barang yang diproduksi oleh perusahaan Tenun Gedogan Putri Rinjani adalah 8 produk. Dengan demikian populasi dalam penelitian ini adalah sebanyak 8 produk. Sampel yang digunakan didalam penelitian ini ialah jenis barang yang paling diminati yakni tenun ikat dan selendang.

Jenis Dan Sumber Data penelitian ini adalah Data kualitatif yaitu data yang berbentuk uraian/penjelasan tentang gambaran umum dari usaha tenun gedogan putri rinjani. Data kuantitatif yaitu data yang berbentuk angka yang diperoleh secara langsung dari laporan keuangan perusahaan.
Sumber Data dalam penelitian ini adalah Data primer, yakni data yang langsung dikumpulkan seorang peneliti dengan cara menyusun data pertanyaan, pengadaan wawancara langsung kepemilik usaha dan elemen produksi. Data sekunder, yakni suatu data yang didapatkan dari objek penelitian yang berbentuk biaya bahan baku, tenaga kerja, danoverhead pabrik serta data tercatat lainnya yang ada kaitannya dengan pembahasan skripsi.

Tekhnik Pengumpulan Data Observasi (pengamatan) ialah, melaksanakan pengamatan secara langsung untuk memperoleh data dalam aktivitas-aktivitas yang berkaitan dengan proses produksi dan data lain yang dibutuhkan. Wawancara Ialah cara mengumpulkan data yang dengan bertanya langsung ke pemilik usaha dan juga karyawan yang berada pada bagian produksi. Dokumentasi Ialah mengumpulkan data dengan melihat catatan/dokumen yang ada didalam perusahaan.

Metode analisis yang dipakai yaitu metode kuantitatif. Data yang diperoleh dari perusahaan tenun gedogan putri rinjani dikumpulkan dan diklasifikasikan sesuai dengan jenisnya. Kemudian data dihutung memakai metode full costing dan variabel costing. Analisa ini memiliki tujuan untuk mengetahui berapa besar HPP menurut full costing, variabel costing dan perusahaan sehingga nantinya dapat dipakai menjadi standar penetapan harga jual produk. 


\section{HASIL DAN PEMBAHASAN \\ Deskripsi Data Penelitian}

Data yang berhasil dikumpulkan dari penelitian ini adalah data yang diperoleh langsung dari pemilik usaha melalui proses wawancara, observasi, dan dokumentasi serta situs web untuk mencari data atau informasi yang sehubungan dengan masalah dalam penelitian ini. Sehingga didapatkan hasil yang lengkap dan akurat untuk menghitung biaya produksi dan keuntungan yang diterima Tenun Gedogan Putri Rinjani setiap bulannya. Sehingga dapat diketahui apakah perusahaan ini mengalami peningkatan penjualan atau malah mengalami penurunan.

Berikut data produksi Tenun Gedogan Putri Rinjani Lombok Timur :

Tabel 4.1

Data Produksi Tenun Gedogan (Tenun Ikat \& Selendang) Tahun 2020 Kembang Kerang Lombok Timur

\begin{tabular}{|c|c|c|c|}
\hline BULAN & $\begin{array}{c}\text { JUMLAH } \\
\text { PRODUKSI }\end{array}$ & $\begin{array}{l}\text { HARGA } \\
\text { SATUAN }\end{array}$ & HARGA PRODUKSI \\
\hline Januari & 92 Tenun Ikat & $\mathrm{Rp} \quad 550.000$ & $\mathrm{Rp} 50.600 .000$ \\
\hline Februari & 100 Tenun Ikat & $\mathrm{Rp} \quad 550.000$ & Rp 55.000.000 \\
\hline Maret & 90 Tenun Ikat & $\mathrm{Rp} \quad 550.000$ & $\mathrm{Rp} 49.500 .000$ \\
\hline April & 95 Tenun Ikat & $\mathrm{Rp} \quad 550.000$ & $\mathrm{Rp} 52.250 .000$ \\
\hline Mei & 90 Tenun Ikat & $\mathrm{Rp} \quad 550.000$ & Rp 49.500 .000 \\
\hline Juni & 98 Tenun Ikat & $\mathrm{Rp} \quad 550.000$ & Rp 53.900 .000 \\
\hline Juli & 95 Tenun Ikat & $\mathrm{Rp} \quad 550.000$ & $\mathrm{Rp} 52.250 .000$ \\
\hline Agustus & 85 Tenun Ikat & $\mathrm{Rp} \quad 550.000$ & $\mathrm{Rp} 46.750 .000$ \\
\hline September & 100 Tenun Ikat & $\mathrm{Rp} \quad 550.000$ & Rp 55.000.000 \\
\hline Oktober & 90 Tenun Ikat & $\mathrm{Rp} \quad 550.000$ & $\mathrm{Rp} 49.500 .000$ \\
\hline Nopember & 95 Tenun Ikat & $\mathrm{Rp} \quad 550.000$ & $\mathrm{Rp} 52.250 .000$ \\
\hline Desember & 85 Tenun Ikat & $\mathrm{Rp} \quad 550.000$ & $\mathrm{Rp} 46.750 .000$ \\
\hline JUMLAH & 1.115 Tenun Ikat & Rp $\quad 550.000$ & Rp613.250.000 \\
\hline Januari & 345 Selendang & $\mathrm{Rp} \quad 150.000$ & Rp 51.750.000 \\
\hline Februari & 350 Selendang & $\mathrm{Rp} \quad 150.000$ & Rp 52.500.000 \\
\hline Maret & 300 Selendang & $\mathrm{Rp} \quad 150.000$ & $\mathrm{Rp} 45.000 .000$ \\
\hline April & 350 Selendang & $\mathrm{Rp} \quad 150.000$ & $\mathrm{Rp} 52.500 .000$ \\
\hline Mei & 330 Selendang & $\mathrm{Rp} \quad 150.000$ & $\mathrm{Rp} 45.000 .000$ \\
\hline Juni & 400 Selendang & $\mathrm{Rp} \quad 150.000$ & $\mathrm{Rp} 60.000 .000$ \\
\hline Juli & 400 Selendang & $\mathrm{Rp} \quad 150.000$ & $\mathrm{Rp} 60.000 .000$ \\
\hline Agustus & 300 Selendang & $\mathrm{Rp} \quad 150.000$ & $\mathrm{Rp} 45.000 .000$ \\
\hline September & 350 Selendang & $\mathrm{Rp} \quad 150.000$ & Rp 52.500.000 \\
\hline Oktober & 300 Selendang & Rp $\quad 150.000$ & $\mathrm{Rp} 45.000 .000$ \\
\hline Nopember & 400 Selendang & 150.000 & $\mathrm{Rp} 60.000 .000$ \\
\hline Desember & 400 Selendang & $\mathrm{Rp} \quad 150.000$ & $\mathrm{Rp} 60.000 .000$ \\
\hline JUMLAH & 4.195 Selendang & Rp $\quad 150.000$ & Rp629.250.000 \\
\hline
\end{tabular}

Sumber : Tenun Gedogan Putri Rinjani

Dari tabel diatas dapat diketahui bahwa, jumlah produksi yang dihasilkan dari bulan januari sampai desember yang terjual adalah sebanyak 1.115 buah Tenun Ikat dengan harga 550.000 sebesar 613.250.000 dan 4.195 buah Selendang dengan harga 629.250.000 jadi Total yang didapatkan sebesar 1.242 .500 .000

Tabel 4.2 
Data Biaya Bahan Baku (Tenun Ikat \& Selendang)

Tenun Gedogan Putri Rinjani

\begin{tabular}{|c|l|c|cr|}
\hline No & Nama Barang & Jumlah & \multicolumn{2}{|c|}{ Harga } \\
\hline 1 & Benang Katun & $5 \mathrm{~kg}$ & $\mathrm{Rp}$ & 880.000 \\
\hline 2 & Benang Rayon & 1 pack & $\mathrm{Rp}$ & 148.000 \\
\hline 3 & Benang Misrae & 1 pack & $\mathrm{Rp}$ & 50.000 \\
\hline 4 & Pewarna Alami & 1 bungkus & $\mathrm{Rp}$ & 50.000 \\
\hline 5 & Pewarna Sintesis & 1 bungkus & $\mathrm{Rp}$ & 20.000 \\
\hline \multicolumn{2}{|c|}{ Jumlah } & & $\mathrm{Rp}$ & 1.148 .000 \\
\hline
\end{tabular}

Sumber : Tenun Gedogan Putri Rinjani

Dari tabel diatas dapat diketahui harga dan bahan baku yang dibeli untuk pembuatan kain tenun selama proses produksi.

Tabel 4.3. Penghasilan Perbulan Yang Didapat (Tenun Ikat \& Selendang)

Tenun Gedogan Putri Rinjani Tahun 2020

\begin{tabular}{|c|c|}
\hline Bulan & Penghasilan \\
\hline Januari & $\mathrm{Rp} 102.350 .000$ \\
\hline Februari & Rp 107.500.000 \\
\hline Maret & $\mathrm{Rp} 94.500 .000$ \\
\hline April & Rp 104.750 .000 \\
\hline Mei & Rp 94.500 .000 \\
\hline Juni & Rp 113.900 .000 \\
\hline Juli & $\mathrm{Rp} 112.250 .000$ \\
\hline Agustus & $\mathrm{Rp} 91.750 .000$ \\
\hline September & Rp107.500.000 \\
\hline Oktober & Rp94.500.000 \\
\hline November & $\mathrm{Rp} 112.250 .000$ \\
\hline Desember & $\mathrm{Rp} 106.750 .000$ \\
\hline Jumlah & $\operatorname{Rp} 1.242 .500 .000$ \\
\hline
\end{tabular}

Sumber : Tenun Gedogan Putri Rinjani

Dari tabel diatas dapat diketahui bahwa jumlah penghasilan yang didapat selama bulan januari-desember 2020 adalah sebesar Rp. 1.242.500.000

\section{HASIL PENELITIAN}

Penelitian ini dititik beratkan pada biaya produksi dan laba yang diperoleh oleh perusahaan Tenun Gedogan Putri Rinjani. Untuk mengetahui biaya produksi dan laba yang diperoleh oleh perusahaan Tenun Gedogan Putri Rinjani, maka akan dipaparkan data-data mengenai bahan baku, biaya tenaga kerja langsung, dan biaya overhead pabrik.

\section{Perhitungan Harga Pokok Produksi Menurut Perusahaan.}

Harga Pokok Produksi:

Biaya Bahan Baku

Biaya Tenaga Kerja Langsung

Biaya Pemeliharaan dan Perbaikan

Biaya Pembelian Alat Yang Kurang

Biaya Penyusutan

Biaya Air, Listrik dan Telpon

Upah pembuatan Motif

Upah Pewarnaan $\begin{array}{lr}\text { Rp } & 546.600 .000 \\ R p & 414.000 .000 \\ R p & 3.000 .000 \\ R p & 5.000 .000 \\ R p & 1.000 .000 \\ R p & 1.580 .000 \\ R p & 12.000 .000 \\ R p & 12.000 .000\end{array}$ 
Upah pembuatan Proses

$\underline{\mathrm{Rp} 12.000 .000+}$

Harga Pokok Produksi

Rp 1.007.180.000

Perhitungan Harga Pokok Produksi Menurut Metode Full Costing

Harga Pokok Produksi:

Biaya Bahan Baku

Rp 546.600.000

Biaya Tenaga Kerja Langsung

Biaya Overhead Pabrik Tetap

Rp 414.000.000

Biaya Overhead Pabrik Variabel

Rp $\quad 1.000 .000$

Harga Pokok Produksi

Rp $45.580 .000+$

Rp 1.007.180.000

Perhitungan Harga Pokok Produksi Menurut Metode Variabel Costing

Harga Pokok Produksi:

Biaya Bahan Baku

Biaya Tenaga Kerja Langsung

Rp 546.600.000

Biaya Overhead Pabrik Variabel

Rp 414.000.000

Harga Pokok Produksi

$\underline{\mathrm{Rp} 45.580 .000+}$

Rp 1.006.180.000

Perbandingan Hasil Perhitungan Menurut Perusahaan, Full Costing dan Variabel Costing

\begin{tabular}{|c|l|c|c|c|}
\hline No & \multicolumn{1}{|c|}{ Uraian } & Perusahaan & Full Costing & $\begin{array}{c}\text { Variabel } \\
\text { Costing }\end{array}$ \\
\hline 1 & Harga Jual & 1.242 .500 .000 & 1.242 .500 .000 & 1.242 .500 .000 \\
\hline 2 & Harga Pokok Produksi & 1.007 .180 .000 & 1.007 .180 .000 & 1.006 .180 .000 \\
\hline 3 & Laba yang diperoleh & 235.320 .000 & 235.320 .000 & 236.320 .000 \\
\hline
\end{tabular}

Dari tabel diatas dapat diketahui Harga Pokok Produksi menurut perusahaan dengan Harga Pokok Produksi menurut metode full costing sama besarnya yaitu 1.007.180.000 sedangkan menurut metode variabel costing sebesar 1.006.180.000, Jadi Harga Pokok Produksi terkecil didapatkan dengan menggunakan metode variabel costing sebesar 1.007.180.000.

Jadi biaya yang lebih kecil dikeluarkan oleh perusahaan Tenun Gedogan Putri Rinjani adalah dengan menggunakan metode variabel costing. Karena metode variabel costing hanya menghitung biaya bahan baku, biaya tenaga kerja langsung, dan Biaya Overhead Pabrik variabel, sedangkan jika menggunakan metode full costing menghitung biaya bahan baku, biaya tenaga kerja langsung, biaya overhead pabrik tetap dan biaya overhead pabrik variabel. Sehingg metode variabel costing mengeluarkan biaya lebih kecil dan mendapatkan laba lebih besar karena tidak menghitung biaya overhead pabrik tetap. Sedangkan perolehan laba yang lebih kecil didapat oleh perusahaan tenun gedogan putri rinjani adalah dengan menggunakan metode full costing karena metode full costing menghitung semua harga pokok produksi yang berperilaku tetap maupun variabel.

Cara Pengambilan Keputusan
1 Dari hasil perhitungan perbandingan metode diatas yang diambil adalah Harga Pokok Produksi Terkecil

(a) Biaya yang dikeluarkan menurut perusahaan adalah sebesar Rp 1.007.180.000

(b) Biaya yang dikeluarkan menggunakan metode full costing adalah sebesar Rp 1.007.180.000

(c) Biaya yang dikeluarkan menggunakan metode variabel costing adalah sebesar Rp 1.006.180.000

(d) Perolehan laba yang didapat menurut perusahaan adalah sebesar Rp 235.320.000

(e) Laba yang diperoleh dengan menggunakan metode full costing sebesar Rp 235.320.000

(f) Dan laba yang didapatkan dengan menggunakan metode variabel costing adalah sebesar Rp 236.320.000.

(g) Tidak ada selisih perhitungan menurut perusahaan dan full costing karena perhitungan Harga Pokok Produksinya sama.

(h) Sehingga selisih perhitungan menurut perusahaan, full costing dengan metode variabel costing sebesar Rp 1.000.000. 
PENUTUP

\section{Kesimpulan}

Berdasarkan kesimpulan dari analisa yang digunakan dalam pembahasan maka, dapat dibuat suatu kesimpulan sebagai berikut:

1. Biaya produksi yang dikeluarkan oleh tenun gedogan putri rinjani selama tahun 2020 adalah sebesar :

(a) Biaya produksi yang dikeluarkan menurut perhitungan perusahaan adalah sebesar 1.007.180.000

(b) Biaya produksi yang dikeluarkan menggunakan metode full costing adalah sebesar 1.007.180.000

(c) Biaya produksi yang dikeluarkan menggunakan metode variabel costing adalah sebesar 1.006.180.000

2. Laba yang diperoleh oleh tenun gedogan putri rinjani selama tahun 2020 menurut perhitungan perusahaan adalah sebesar 235.320.000

3. Laba yang diperoleh oleh tenun gedogan putri rinjani selama tahun 2020 menurut metode full costing adalah sebesar 235.320.000

4. Laba yang diperoleh oleh tenun gedogan putri rinjani selama tahun 2020 menurut metode variabel costing adalah sebesar 236.320.000

\section{Keterbatasan Penelitian}

Keterbatasan dalam melakukan penelitian ini adalah sebagai berikut:

1. Keterbatasan dari proses penelitian adalah sulitnya melakukan pengumpulan data karena sumber data yang berupa arsip tidak lengkap sehingga harus dihitung ulang.

2. Keterbatasan selama melakukan penelitian perusahaan tidak bersifat terbuka. Perusahaan tidak bersedia untuk memberikan data-data lengkap yang dibutuhkan berdasarkan perkiraan, sehingga kesimpulan yang diambil hanya sebatas data yang diperoleh selama penelitian dilakukan.

\section{SARAN}

Berdasarkan kesimpulan dari hasil penelitian diatas, maka peneliti menyarankan sebagai berikut :

1. Bagi pemilik usaha tenun gedogan putri rinjani, hasil penelitian ini diharapkan dapat memberikan masukan pemikiran pada usaha tenun gedogan putri rinjani dengan menentukan harga pokok produksi yang lebih akurat terutama dalam menghadapi persaingan harga penjualan.

2. Perbedaan yang terjadi dalam perhitungan harga pokok produksi menurut metode full costing dan variable costing harus menjadi perhatianperhatian khusus dari pemilik perusahaan dalam menentukan harga pokok produksi. Tindakan yang harus diambil adalah dengan melakukan koreksi pada perhitungan harga pokok produksi harus sesuai dengan metode full costing dengan menghitung dan mengidentifikasikan biaya bahanbaku, biaya tenaga kerja langsung dan biaya overhead pabrik.

3. Penulis menyarankan sebaiknya perusahaan menggunakan metode variabel costing dalam menghitung harga pokok produksi. Karena dalam metode variabel costing dihitung semua biaya yang hanya berkaitan langsung dalam proses produksi.Alasannya adalah karena komponen biaya yang terdapat dalam metode variable costing dipisahkan berdasarkan perilaku biayanya, yaitu biaya yang berperilaku variabel dibebankan ke dalam harga pokok produksi sedangkan biaya yang berperilaku tetap dipisahkan menjadi biaya periodik.

4. Bagi peneliti lain yang akan melakukan penelitian sejenis diharapkan menggunakan objek penelitian lain, peneliti tidak terpaku pada perusahaan manufaktur saja.

\section{DAFTAR PUSTAKA}

Ajat rukajar (2018) Pendekatan penelitian kuantitatif (quantitative research approach)cv budi utama. yogyakarta.

Andy Wijaya, Sisca, Hery Pandapotan Silitonga dkk (2020)Manajemen Operasi Produksi

Bastian Bustami \& Nurlela. 2006. Akuntansi Biaya : Kajian Teori Dan Aplikasi. Edisi Pertama. Yogyakarta : Graha Ilmu

Cahyani Galuh Fitri Nur (2015) “ Analisis Perhitungan Harga Pokok Produksi Dengan Metode Full Costing Pada Pabrik Tahu Sari Langgeng Kutoarjo

Djumali Indro(2014) dengan judul penelitian “ Perhitungan Harga Pokok Produksi Menggunakan Metode Variabel Costing Dalam Proses Penentuan 
Harga Jual Pada PT. Sari Malalugis Bitung.

R.A Supriyono (2014).Akuntansi Biaya.Perencanaan Dan Pengendalian Biaya Serta Pembuatan Keputusan.

Dadan Ramdhani Dkk(2020) Akuntansi Biaya.konsep dan implementasi di industri manufaktur. Yogyakarta. Cv.Markumi.

Emi Iryanie dan Monika Handayani(2019) Akuntansi Biaya.Edisi pertama. Banjarmasin: Polibanpress

Febrianty (2020) "Analisis Perbandingan Metode Full Costing Dan Variabel Costing Dalam Penetapan Harga Pokok Produksi (Studi Pada Perusahaan Daerah Air Minum Tirta Je'neberang Kabupaten Gowa).

Hadi Gigih Radhian (2015) "Analisis Penentuan Harga Pokok Produksi Dengan Menggunakan Metode Variabel Costing Dan Full Costing Di UD. Cahaya Rembulan Kecamatan Pringgabaya Kabupaten Lombok Timur

Ingga, I. (2017). Akuntansi Biaya. Jakarta.

Mulyadi (2015).Akuntansi biaya. Edisi 5

Narkubo Cholid dan Achmadi Abu.(2005). Metodologi penelitian. Jakarta. PT bumi aksara

Oktaviani (2019) “Analisis Perhitungan Harga Pokok Produksi Dengan Metode Full CostingStudi Kasus Pada Cv. Lestari Albasia Mandiri.

Rohmiatun (2016) "Analisis Perhitungan Harga Pokok Produksi Dengan Menggunakan Metode Full Costing Dan Variabel Costing Study Kasus
Pada Industri Rumah Tanggan UD.Nandita Pancor Lombok Timur

Silvia Porawouw (2013) Analisis Perbandingan Metode Penentuan Harga Pokok Produksi Pada Pt. Bangun Wenang Beverages Co

Sri Wahyuni Nur. (2020). Akuntansi Dasar. Teori dan Teknik penyusunan laporan keuangan. Makassar. cendekia Publisher

Sriyani, I. (2018). Skripsi Analisis Perhitungan Harga Pokok Produksi Dengan Metode Full Costing dan Variabel Costing. Medan.

Sulastri (2019) Analisis Perhitungan Harga Pokok Produksi Menggunakan Metode Full Costing Dan Metode Variabel Costing Pada Warung Pempek Nony 168 Palembang Cabang Radial

Sunanda (2019) “Analisis Harga Pokok Produksi Menggunakan Metode Full Costing,Variable Costing Dan Activity Based Costing Untuk Penentuan Harga Jual Produk Pada Rolasz Group ( Studi Kasus Pada Usaha Konfeksi Rolasz Group ).

Sunarno Sastro Admodjo dan Eddy Purnairawan (2021) PENGANTAR AKUNTANSI Jawa barat cv media sains indonesia.

Suryadi prawirosentono (2009) manajemen operasi( operations management) jakarta bumi aksara.

T. Horngren 2006. Akuntansi Biaya : Dengan Penekanan Manajerial Edisi Keduabelas Jakarta : Erlangga

Widya Ais Sahla (2020) Akuntansi Biaya (Panduan Perhitungan Harga Pokok Produksi) Banjarmasin Poliban Press. 